\title{
A experiência sinodal no Cristianismo antigo dos séculos II a IV
}

\author{
The synodal experience of ancient Christianity from the 2nd \\ to the 4th centuries
}

Luiz Antônio Pinheiro

\section{Resumo}

O Papa Francisco propõe a "sinodalidade" como "via mestra da vida da Igreja". Para "caminhar juntos" hoje, podemos buscar inspiração na tradição sinodal do cristianismo antigo. Um de seus aspectos mais característicos era a busca da unidade da fé e da disciplina entre as numerosas comunidades cristãs, dispersas pelo Império Romano. A realização de sínodos ou concílios foi o caminho encontrado para viver a comunhão entre as Igrejas em âmbito regional, local e universal. A praxe sinodal nasceu no século II, desenvolveu-se no século III e, ao encontrar a maturidade no início do século IV, desembocou na instituição do concílio ecumênico. O Concílio de Niceia abriu uma nova etapa na história do cristianismo. Há uma continuidade e descontinuidade entre os concílios desses três séculos e os grandes concílios ecumênicos da antiguidade cristã. Neste artigo queremos apresentar, de maneira panorâmica, a evolução dessa praxe, com suas características, eclesialidade emergente e seu significado para o caminho sinodal da Igreja nos tempos atuais.

Palavras-chave: Igreja Antiga. Concílio. Sínodo. Colegialidade. Sinodalidade.

\section{Abstract}

Pope Francis proposes "synodality" as "the way of life of the Church". To "walk together" today, we can look to the synodal tradition of ancient Christianity for inspiration. One of its most characteristic aspects was the search 
for the unity of faith and discipline among the numerous Christian communities, dispersed throughout the Roman Empire. The holding of synods or councils was the way found to live communion between the Churches at regional, local and universal levels. The synodal praxis was born in the 2nd century, developed in the 3rd century and, when it matured in the beginning of the 4th century, it ended up in the institution of the ecumenical council. The Council of Niceia opened a new stage in the history of Christianity. There is a continuity and discontinuity between the councils of these three centuries and the great ecumenical councils of Christian antiquity. In this article we want to present, in a panoramic way, the evolution of this practice, with its characteristics, emerging ecclesiality and its meaning for the Church's synodal path in the present times.

Keywords: Ancient Church. Concil. Synod. Collegiality. Synodality.

\section{Introdução}

Na comemoração dos 50 anos da instituição, do Sínodo dos Bispos, criado por Paulo VI (15/09/1965), o Papa Francisco declarou: "Aquilo que o Senhor nos pede, de certo modo está já tudo contido na palavra 'Sínodo'. Caminhar juntos leigos, pastores, Bispo de Roma - é um conceito fácil de exprimir em palavras, mas não é assim fácil pô-lo em prática”. O Papa propõe a sinodalidade como a "via mestra da vida da Igreja": "O caminho da sinodalidade é precisamente o caminho que Deus espera da Igreja do terceiro milênio". ${ }^{1}$

Inspirando-se nas palavras de Francisco, a Comissão Teológica Internacional conduziu, em 2018, um estudo sobre a sinodalidade na vida e na missão da Igreja. Segundo o documento, sinodalidade significa "o específico modus vivendi et operandi da Igreja Povo de Deus, que manifesta e realiza concretamente o seu ser comunhão no caminhar juntos, em reunir-se em assembleia e na participação ativa de todos os seus membros na sua missão evangelizadora". ${ }^{2}$ Tamanha é a importância que o Papa concede a essa dimensão demonstra-o sua decisão de convocar a XVI Assembleia Geral Ordinária do Sínodo, prevista para o mês de outubro de 2022 com esse tema: "Por uma Igreja sinodal: comunhão, participação e missão".

\footnotetext{
${ }^{1}$ FRANCISCO, Commemorazione del $50^{\circ}$ Anniversario dell'Istituzione del Sinodo dei Vescovi.

${ }^{2}$ CTI, A sinodalidade na vida e na missão da Igreja, 6 .
} 
Segundo o Papa Francisco, o Sínodo dos Bispos é "novo quanto à instituição, mas muito antigo na sua inspiração". ${ }^{3}$ Na realidade, os concílios ou sínodos destacam-se como uma das mais importantes manifestações da vida eclesial dos primeiros séculos. No cristianismo antigo, as comunidades procuravam manifestar sua comunhão umas com as outras por meio de encontros, assembleias e intercâmbio epistolar (At 15,22-32). ${ }^{4}$

No presente artigo, depois de fazermos uma aproximação terminológica e discorrer sobre a "colegialidade" e "sinodalidade" no Novo Testamento, daremos notícia do surgimento dos primeiros sínodos ou concílios, prática seguramente atestada desde o século II. A seguir, forneceremos uma visão panorâmica do desenvolvimento da praxe conciliar do século II ao século IV, oferecendo maiores detalhes de alguns concílios por regiões, contextualizado algumas das principais questões abordadas, principalmente nos concílios de Cartago, Roma, Elvira e Arles. Destacaremos, por fim, algumas características principais e a eclesiologia emergente dos concílios pre-nicenos, que prepararam o advento dos grandes concílios ecumênicos, além de apontar alguns aspectos de continuidade e descontinuidade entre estes e aqueles.

\section{Aproximação terminológica}

Influenciados pelos "modelos" cunhados no sinédrio, nas sinagogas judaicas e no senado romano, os termos sínodos ou concílios eram usados como sinônimos $(\sigma \dot{v} v o \delta o \varsigma=$ concilium $)$. Mas é necessário apontar-lhes algumas particularidades em sua evolução semântica e institucional.

Os seguidores de Jesus entendiam suas reuniões de uma maneira muito particular, dando um novo significado a termos emprestados da tradição judaica ou da gentilidade. ${ }^{5}$ Mesmo continuando a frequentar o Templo, privilegiam as reuniões nas casas, onde "eram assíduos à pregação dos apóstolos, fiéis à comunhão fraterna, à eucaristia, às orações" (At 2,42). Aos elementos da reunião sinagogal (leituras, cantos, orações, eventualmente homilia), os cristãos somam a fractio panis. Preferiam o verbo ao substantivo: ovvóyєıv (reunir), de

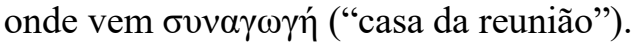

A própria reunião continua às vezes a chamar-se $\sigma 0 v \alpha \gamma \omega \gamma \eta ́$, mas os

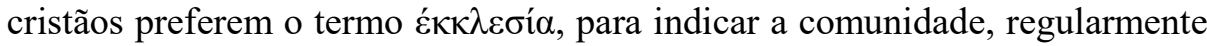
convocada para expressar sua unidade e movimentação permanente, de maneira

\footnotetext{
${ }^{3}$ FRANCISCO, Constituição Episcopalis Communio sobre o Sínodo dos Bispos, 1.

${ }^{4}$ DI BERARDINO, A., Percursos de koinonia nos primeiros cristãos, p. 49.

${ }^{5}$ LECLERCQ, H., Synode, col. 1837.
} 
semelhante às assembleias litúrgicas do Antigo testamento, chamadas qahal, mas com a novidade de se sentirem convocadas para celebrar o "memorial do Senhor". A assembleia expressa visivelmente o vínculo e a unidade dos cristãos, os quais, mesmo na sua dispersão, formam "um coração e uma só alma", um só corpo, como é simbolizado pelo único pão composto de diversos

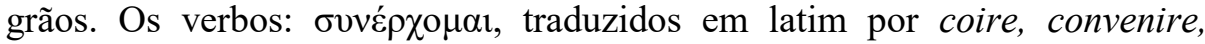

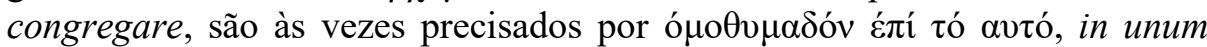
(Atos, Paulo, Inácio). O povo reunido se entende como ecclesia (forma transliterada do latim), que primeiro indica a reunião em comunidade e depois o lugar da reunião da comunidade (domus ecclesiae). Os gregos preferem o termo $\sigma u ́ v \alpha \xi 1 \varsigma$ (Orígenes, Cirilo de Jerusalém).

Na latinidade clássica, os romanos utilizavam três palavras para designar suas assembleias de caráter público: contio, comitia/concilium e colleguium. ${ }^{6}$ Contio designava qualquer tipo de assembleia em geral; comitia e concilium denotavam as diversas espécies de reuniões de assembleias deliberativas, não tanto para discutir os problemas, mas para resolvê-los mediante eleições ou votações, legislação ou um juízo. O termo collegium servia para designar qualquer tipo de convenção ou associação de homens, ao menos três, da mesma dignidade e honra, ofício ou arte, chamados também de collegarum societas (pontificum, augurum, haruspicum, quaestorum, tribunorum, etc). O termo era empregado tanto para um agrupamento daqueles que tinham um mesmo ofício ou se reuniam para defender seus interesses como aqueles que conspiravam contra a coisa pública. No mundo grego havia assembleias ou reuniões de diversas organizações da pólis ou de cidades federadas, conhecidas por uma

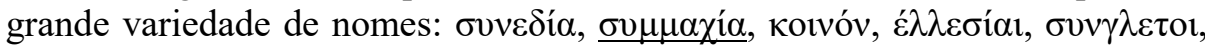
que aconteciam anualmente e eram menos complexas que os comitia romanos.

A palavra concilium aparece em diversos textos da Vetus latina, com

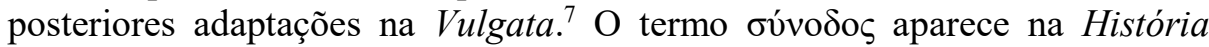
Eclesiástica $(H E)$ de Eusébio de Cesareia para designar as reuniões dos bispos

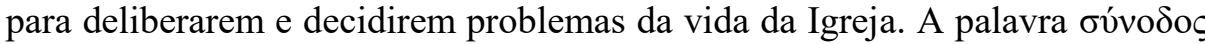
passou ao latim como calco lexigográfico com as variantes synhodus, synodus, sinhodus, sinodus e terá o mesmo significado de concilium em âmbito eclesial.

Num primeiro momento, synodus era utilizado em sentido comum, sem uma conotação especificamente cristã. A primeira atestação conhecida da

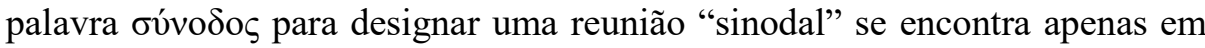

${ }^{6}$ FARRELL, J., The Distinction between comitia and concilium, p. 407-408.

${ }^{7}$ Em códices da Vetus latina, lugdunensis e itala, p.ex.: "qui autem dixerit fratri suo racha, reus erit concilio" (Mt 5,22); “collegerunt ergo principes sacerdotum et pharisaei concilium” (Jo 11,47). 
Dionísio de Alexandria. ${ }^{8}$ Tertuliano e Cipriano utilizam concilium para as assembleias eclesiásticas. Entre os Padres da Igreja observa-se uma alternância no uso dos termos concilium e synodus, como sinônimos, até adquirirem um sentido técnico, numa longa evolução semântica. Na latinidade cristã antiga há ainda outras expressões para designar uma reunião de caráter eclesial: conventus (episcopalis, episcoporum, sacerdotalis, synodalis). Posteriormente, cada sessão de um sínodo será chamada conventus. Para uma assembleia utilizava-se também coetus.

\section{A colegialidade e sinodalidade no Novo Testamento}

Os termos "colegialidade" e "sinodalidade" são neologismos que não se encontram no Novo testamento. No entanto, pode-se fundamentar a praxe posterior da colegialidade e da sinodalidade como uma realidade da vida apostólica e das primeiras comunidades. ${ }^{9}$ Diante de questões e novas dificuldades, a Igreja procurou responder aos problemas de maneira "colegial".

No Novo testamento, os "Doze" aparecem nitidamente como um "colégio"; não agem individualmente, mas colegialmente. A tradição evangélica é unânime em apresentá-los como enviados de Jesus, uma missão já presente na vida terrena do Cristo. Pedro aparece como o líder e porta-voz dos demais. Essa "colegialidade" acompanha o nascimento e difusão da Igreja. O ideal da Igreja do Novo Testamento é o de um corpo organizado, no qual os apóstolos têm o primeiro lugar, um edifício onde o seu "colégio" constitui o fundamento. Mesmo que apareça como um carismático que se apoia somente sobre suas próprias visões, Paulo possui, de fato, uma postura "colegial", tem uma visão eclesial de unidade, fundada sobre os apóstolos. Cioso desta realidade, ele dirigiu-se a Jerusalém, acompanhado de Barnabé e Tito, para se encontrar com os outros apóstolos (Gl 1,1.12; 2,1-15; 1Cor 15,9; 12,27-30; Ef 2,19-20; 3,5; 1Cor 13,3-39).

A primeira crise da Igreja, o conflito entre judaizantes e helenizantes, foi resolvida num "sínodo", anacronicamente chamado de "concílio de Jerusalém", com a presença dos apóstolos, dos anciãos e os enviados da Igreja de Antioquia, Paulo e Barnabé. Estava em causa a questão da admissão dos pagãos à comunidade cristã. $\mathrm{Na}$ "carta apostólica", enviada à comunidade de Antioquia,

\footnotetext{
${ }^{8}$ EUSÉBIO DE CESAREIA, HE, VII,5,7 e 7,5.

${ }^{9}$ BOTTE, B., La collégialité dans le Nouveau Testament et chez les Pères apostoliques, p. 1-18.
} 
aparece a fórmula que se tornou paradigmática para a posteridade: "Pareceu bem ao Espírito Santo e a nós" (At 15, 6-23).

Nos Padres Apostólicos, notamos uma grande preocupação com a unidade da Igreja. Diante dos perigos que a ameaçavam, tanto internos (os falsos messias e profetas, os contestadores) como externos (as calúnias, perseguições e os gnósticos), os primeiros Padres desenvolveram uma reflexão apoiada em três aspectos: a fundação da Igreja sob o colégio apostólico, a tradição apostólica ( $\alpha \pi 0 \sigma \tau 0 \lambda \iota \kappa \eta ́ ~ \pi \alpha \rho \alpha ́ \delta o \sigma ı \varsigma)$ e a autoridade da tradição viva da Igreja, representada pelos bispos.

Apesar da autonomia de cada comunidade eclesial, as Igrejas não viviam fechadas em si mesmas. Inácio de Antioquia é o primeiro a falar em $\dot{\eta} \kappa \alpha \theta 0 \lambda \iota \kappa \eta ́$ $\dot{\varepsilon} \kappa \kappa \lambda \eta \sigma i ́ \alpha .{ }^{10}$ Esta convicção de ser "a Igreja católica", de estar na unidade da Igreja, supõe uma unidade de fé e disciplina. Por volta da metade do século II, encontramos uma Igreja viva (a "grande Igreja", na expressão de Celso), que se opõe às seitas e procura manter a unidade da fé tendo como base a tradição dos apóstolos, consignada no depositum, custodiado pelos bispos e transmitido pelos seus sucessores, conforme sistematizou posteriormente Ireneu de Lião, em sua obra Contra as Heresias.

\section{O nascimento da prática sinodal}

Nos meados do século II, as primeiras assembleias episcopais acontecem no desenvolvimento da dinâmica eclesial, caracterizada pela formação do cânon escriturístico, instituição da penitência e do catecumenato, elaboração da noção de sucessão apostólica do episcopado, ortodoxia e heresia, tendo como base a autoridade da tradição viva, que discernia a regula ou disciplina fidei, condensada no symbolos ou credo, professado solenemente na liturgia. ${ }^{11}$ Processava-se uma paulatina regularização das relações entre os bispos, estabelecendo critérios para sua escolha, ordenação e reconhecimento na communio entre as Igrejas. Há um consenso de que o núcleo germinal da praxe sinodal esteja no encontro dos bispos de uma mesma região para sancionar, através da ordenação, a designação que a comunidade local havia feito de seu bispo. ${ }^{12}$

O episcopado tomou consciência de ser responsável por uma comunidade apostólica prolongada em seus sucessores (ordo episcoporum), sendo necessário deliberar decisões comuns para as Igrejas. Dessa forma, os concílios aparecem

${ }^{10}$ INÁCIO DE ANTIOQUIA, Epístola aos Filadelfienses, 3,2.

${ }^{11}$ MAROT, H., Conciles anténicéens et conciles oecuméniques, p. 19-43.

${ }^{12}$ ALBERIGO, G., Prefácio, p. 5. 
segundo a natureza dos problemas a serem resolvidos (daí o caráter local, regional, provincial e depois universal). Aconteciam de acordo com a "geografia eclesiástica e missionária". Pouco a pouco algumas Igrejas iam se sobressair como Igrejas-mãe, entre as quais as mais importantes eram Antioquia, Cesareia, Alexandria, Aquileia, Lião, Cartago e Roma, evidentemente. Em geral, o bispo da Igreja mais antiga presidia o sínodo de sua região. ${ }^{13}$

$\mathrm{Na}$ Ásia Menor, na região da Frígia, por volta de 175 apareceu a "nova profecia", ${ }^{14}$ anunciada por Montano, secundado pelas profetisas-diaconisas Prisca e Maximila. O montanismo, de caráter entusiástico, moral rigorista, anunciava a nova vinda do Espírito Santo. Negava a Igreja-institucional, não reconhecia a autoridade dos bispos e se considerava superior à Escritura. No entanto, era ortodoxo do ponto de vista dogmático. Os bispos reuniram-se em assembleias regionais, que não iam além de uma província civil. Atestada a participação de leigos. ${ }^{15}$

$\mathrm{O}$ debate em torno à controvérsia pasca ${ }^{16}$ inaugura a prática sinodal, ao envolver um número considerável de Igrejas. ${ }^{17}$ A partir de 190, o bispo de Roma, Vítor I, provocou uma série de "sínodos" desde Lião até a Mesopotâmia, a fim de obter a adesão de todas as Igrejas para a celebração da Páscoa de acordo com o uso romano. Realizaram-se reuniões sincrônicas no Ocidente e no Oriente, estreitamente unidas por relações epistolares: sínodo romano, sínodo dos bispos da Ásia, sínodo da Palestina e da Síria do Sul, sínodo dos bispos da Osroena. Destacaram-se a autoridade do bispo de Alexandria e a posição da imensa diocese da Gália. Ambas eram do parecer que cada Igreja continuasse com o seu costume. Roma recebeu uma carta sinodal a esse respeito.

Em 193, realizou-se um sínodo em Roma, convocado por Vítor. Este sínodo é o primeiro do qual se tem notícia certa de ter sido realizado no Ocidente. Os asiáticos, mesmo em minoria, mantiveram sua data, uso quatordecimano. Os bispos da Ásia Menor, liderados por Polícrates de Éfeso, declararam não querer seguir a prática romana. Vítor pretendia excluí-los da comunhão com Roma, mas foi dissuadido graças à intervenção de alguns bispos, entre os quais Ireneu de Lião, que o exortaram a respeitar a tradição de cada Igreja. Provisoriamente a questão ficou sem solução e só foi resolvida no Concílio de Arles (314) e posteriormente chancelada pelo concílio de Niceia.

${ }^{13}$ ZEILLER, J., L'organizzazione ecclesiastica, p. 522.

${ }^{14}$ EUSÉBIO DE CESAREIA, HE, V,16,10.

${ }^{15}$ DI BERARDINO A.; GROSSI, V., La Chiesa antica, p. 281-282.

${ }^{16}$ EUSÉBIO DE CESAREIA, HE, V,23,3.

${ }^{17}$ JUNOD, E., Naissance de la pratique synodale et unité de l’Église au IIe. Siècle, p. 163-180. 


\section{Visão panorâmica do nascimento e desenvolvimento da praxe conciliar: século II a IV}

Já no século II constata-se a prática sinodal, primeiro na Ásia (Anatólia, Síria, Palestina) e na Itália; multiplicam-se os sínodos no século III, principalmente na África, mas também em outras regiões, começando a desenvolver-se lentamente nas Gálias; há uma preponderância das assembleias sinodais no Egito (Alexandria); registra-se um caso peculiar na Espanha (Elvira); os concílios romanos. No início do século IV, já no contexto da guinada constantiniana, temos dois concílios paradigmáticos, que se tornaram uma experiência preparatória do primeiro grande concílio ecumênico, o Concílio de Niceia (325).

Em 267, Diocleciano promoveu uma nova reorganização das províncias do Império Romano. Acentuou-se a tendência de a Igreja organizar-se de acordo com as estruturas administrativas do Império. A partir de então firmou-se a prática de se realizar os concílios de acordo com a divisão das províncias imperiais. O Concílio de Niceia homologou-as como "províncias eclesiásticas". Em geral, o bispo da capital da província civil era chamado de metropolita e teve maior ou menor influência sobre as dioceses da província, de acordo com a história própria de cada região. ${ }^{18}$ A Igreja antiga desenvolverá, a partir de sua

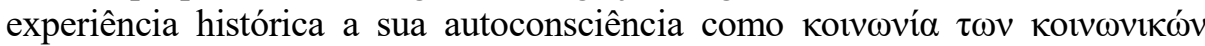
(comunhão de comunhões), cuja maior expressão institucional foi a pentarquia. ${ }^{19}$

Vejamos agora, os principais concílios por regiões, abordando alguns aspectos de sua realização, participantes, medidas tomadas. Destacamos alguns concílios realizados no Oriente (Icônio, Alexandria, Arábia Pétrea e Antioquia); Cartago, Elvira; Roma e Arles.

\subsection{Concílios no Oriente}

No Oriente ocorreram vários concílios, como o de Icônio, Alexandria, Arábia Pétrea e Antioquia. Em Icônio (230-235), participaram bispos provenientes da Frígia, Galácia, Cilícia e regiões vizinhas, e Cesareia da Capadócia. Nele se examinou a validade do batismo administrado pelos

\footnotetext{
${ }^{18}$ ZEILLER, J., L’Organizzazione ecclesiastica, p. 572. Os bispos metropolitas das sés maiores serão chamados patriarcas, constituindo a pentarquia, os cinco grandes patriarcados: Roma, Antioquia, Alexandria, Jerusalém, Constantinopla.

${ }^{19}$ DI BERARDINO, A., Presentazione, p. 5.
} 
hereges, principalmente montanistas. Tal batismo deveria ser considerado inválido e, portanto, quem os tivesse recebido deveria ser rebatizado.

Em Alexandria, aconteceu um concílio em 231/232, convocado por Demétrio e do qual participaram bispos egípcios e alguns presbíteros. ${ }^{20}$ Nele Orígenes foi julgado por ter-se ordenado presbítero, sem o consentimento de Demétrio, seu bispo. Na verdade, Orígenes, aberto à contribuição da cultura grega, suscitava dissensões, e algumas de suas doutrinas eram discutíveis; a sua própria notoriedade fazia sombra a Demétrio. O concílio proibiu Orígenes de residir e ensinar em Alexandria. Demétrio, com o apoio de alguns bispos egípcios, invalidou sua ordenação sacerdotal. A condenação foi aprovada pelo bispo de Roma e por outros, mas não pelos bispos da Palestina, Síria, Grécia e Arábia, onde Orígenes encontrou abrigo, principalmente da parte do prestigioso bispo de Cesareia, Eusébio. Atanásio fala de um concílio reunido por Pedro de Alexandria (305 ca.), para condenar Melício de Licópoli, culpado de ter imolado aos ídolos e outros delitos. Na realidade, Melício foi condenado por ter realizado ordenações irregulares de bispos durante a perseguição de Diocleciano e porque não aprovava as providências moderadas de Pedro em relação aos lapsi dessa perseguição.

Entre 246-250 (ou 244-249), realizou-se um concílio em Arábia Pétrea convocado para corrigir alguns erros acerca da sobrevivência da alma. Eusébio narra que, segundo os arabici, a alma morre com o corpo e na ressurreição voltará à vida (doutrina hipnopsíquica). ${ }^{21}$ As reuniões tinham dado pouco resultado em persuadir os arabici, enquanto não chegou Orígenes, quem, com a sua preparação doutrinal, dissipou-lhes o erro.

Antioquia entra no movimento sinodal em 252, envolvendo várias sés orientais e preparou assim ossatura que permitiu a realização do Concílio de Niceia. ${ }^{22}$ Nos anos de 264 e 268 realizaram-se dois sínodos em Antioquia, desta vez contra Paulo de Samosata, ocasião em se debateu também um tema de caráter trinitário-cristológico. O sínodo de 268 endereçou sua carta sinodal a Roma, Alexandria e outras Igrejas, buscando fortalecer a comunhão da Igreja

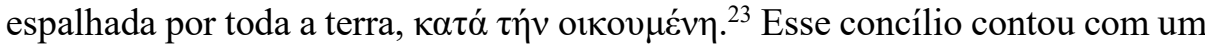
número considerável de bispos, entre 70 e 80 . Havia bispos da Síria, Palestina

\footnotetext{
${ }^{20}$ SIMONETTI, M., Alessandria. Concili, col. 121.

${ }^{21}$ EUSÉBIO DE CESAREIA, HE, VI, 37; NARDI, C., Arabia, col. 304-306.

${ }^{22}$ SIMONETTI, M., Antiochia di Siria. Concili. col. 233.

${ }^{23}$ EUSEBIO DE CESAREIA, HE, VII,28,1; 30,1; 30,2.
} 
e Ásia Menor, reunidos para julgar o bispo local Paulo de Samosata, acusado de heresia e imoralidade. ${ }^{24}$

\subsection{Concílios de Cartago}

A Igreja de Cartago era zelosa de sua tradição e prezava por sua autonomia, principalmente frente à Igreja de Roma. Em Cartago realizaram-se muitos concílios, desde tempos antigos. Nos escritos de Cipriano e Agostinho frequentemente encontramos referências a concílios realizados desde os finais do século II. Sob a presidência de Cipriano, realizaram-se em Cartago sete concílios, dos quais temos apenas informações fragmentares, em boa parte graças às suas cartas. Esses concílios, em conexão com os realizados em Roma na mesma época, estão intimamente ligados à perseguição aos cristãos promovida pelo imperador Décio. ${ }^{25}$

Em 249-251, Décio promoveu a primeira perseguição sistemática aos cristãos, que acarretou um grande número de caídos (lapsi). Mais do que mártires a autoridade imperial objetivava a apostasia. Após a morte de Décio, ocorreu um período anárquico, com a sucessão de vários imperadores, até a ascensão de Valeriano (253-260), que promoveu nova perseguição a partir de 257, cessada por seu filho Galeno, após a morte do pai. No conjunto houve também um grande número de mártires. Passada a primeira fase da perseguição, um bom número de lapsi quis retornar ao seio da Igreja. Formaram-se dois partidos quanto à penitência a ser imposta: os rigoristas negavam a absolvição e os laxistas preconizavam a misericórdia, com uma pedagógica e proporcional penitência, de acordo com a gravidade da falta. Entre os rigoristas estava Novaciano, que ambicionava a sé de Roma na sucessão de Fabiano, que fora martirizado. No entanto, a eleição de Cornélio levou os apoiadores de Novaciano a provocarem um cisma. ${ }^{26}$

Realizaram-se na época numerosos concílios na Itália e na África. O concílio de Cartago (251) adotou uma conduta rigorosa com os lapsi. O concílio romano condenou o rigorismo de Novaciano e adotou uma medida moderada. Desenvolveu-se grande contato epistolar entre as várias sés. Um dos graves problemas tratados nesses concílios refere-se à validade do batismo administrado pelos hereges ou cismáticos: é válido o batismo dos novacionistas que querem retornar à Igreja? Neste momento, surgiu a questão do "primado da

${ }^{24}$ EUSÉBIO DE CESAREIA, HE, VII, 27-30

${ }^{25}$ MUNIER, C., Cartagine. Concili, col. 601-602.

${ }^{26}$ DI BERARDINO, A.; GROSSI, V., La Chiesa antica, p. 282-290. 
Igreja de Roma”, plenamente consciente de sua primazia e o tema da autoridade dos concílios, que não tinham em si mesmos um critério absoluto. Em Roma, sucederam-se os bispos Fabiano (236-250), Cornélio (251-253), Lúcio I (253254), Estêvão I (254-257) e Sisto II (257-258). Cipriano (248-258) atravessou esse período e pode anunciar o martírio de Sisto um pouco antes dele mesmo ser martirizado (258).

Com relação à questão dos lapsi, tanto Roma como Cartago estavam de acordo com a aplicação de uma penitência moderada e discriminada de acordo com a gravidade da falta. No entanto, enquanto Cartago reafirmava reiteradamente sua tradição de rebatizar hereges e cismáticos, Roma mantinhase firme na posição de não rebatizar. Cartago obteve o apoio das sés orientais, conseguindo a adesão unânime em relação à tradição africana. Estevão, intransigente, excomungou Cartago e as sés da Síria e Ásia Menor, que a acompanhavam. Este ponto ficou irresoluto, pois os três maiores representantes da polêmica, Estêvão (inflexível na posição romana), Sisto II (moderado e conciliador) e Cipriano (firme na posição africana) pereceram na última fase da perseguição de Valeriano. A solução só foi encontrada através de uma posição mediana nos Concílios de Arles (314), ratificada por Niceia (325). Seguiramse ainda muitos outros concílios em Cartago depois da paz constantiniana, vários dos quais retomaram a questão do rebatismo dos hereges, vencendo, por fim, na época de Agostinho, a observância romana, de não rebatizar. A invasão dos Vândalos pôs fim à atividade conciliar na África do Norte. Somente no início do séc. VI essa prática renascerá, mas por pouco tempo.

\subsection{O Concílio de Elvira}

No início do século IV, realizou-se na Hispania um concílio de grande importância, ocorrido na cidade de Elvira, em data não de todo precisa (entre 295 e 314). Elvira era uma pequena cidade situada na província Bética (atual Andaluzia). Hoje é um bairro da cidade de Granada, na Espanha. As atas fornecem apenas o dia: 25 de maio. Constam 86 cânones! Assinam 19 bispos e 24 presbíteros, delegados de 37 comunidades cristãs. Pode-se falar propriamente de um "concílio nacional", havendo representantes de cinco províncias romanas: Bética, Cartago, Lusitânia, Tarraconense e Galícia. A importância deste concílio é notável porque nos dá a conhecer a Igreja "espanhola" da época. ${ }^{27}$

${ }^{27}$ DE LUIS, Elvira (Concilio di), col. 1144-1145. 
Constata-se a ampla difusão do cristianismo na península, sobretudo na Bética, como em seus vários estratos sociais, uma vez que os documentos enumeram tanto as cidades e províncias como várias categorias sociais nos temas tratados. Infere-se a pouca eficácia da cristianização, porque se depreende que ainda existia idolatria entre os cristãos (can. 1); estes assistiam ao culto pagão (can. 59); havia ídolos nas casas (can. 41); os cristãos esposavam-se com pagãos e judeus (can. 15,16,17); até mesmo os bispos acreditavam em malefícios e eram notavelmente permissivos em matéria de vida matrimonial e sexual.

Deve-se notar ainda certa rigidez nas penas impostas, incluindo a exclusão total da Igreja dos usurários recidivos (can. 20), dos detentores de ídolos nas próprias casas (can. 41), daqueles que pediam bênçãos aos judeus de suas coletas (can. 49) e dos aurigas e comediantes que não tinham cumprido a promessa de abandonar a sua atividade (can. 62). Há também penas muito duras, como a exclusão da comunhão (eclesial ou eucarística) em ponto de morte, ameaçada sobretudo pelos pecados de fornicação e contra o matrimônio. $\mathrm{O}$ can. 25 refere-se aos que recebem o título de confessores; o can. 60 não reconhece como mártires aqueles que morrem só por terem destruído ídolos; o can. 73 fala de delatores dos cristãos.

O concílio quer intensificar a vida cristã, libertando-a de todas as ataduras e resíduos pagãos, de todo contato com os judeus e quer com toda insistência tornar exemplar a vida do clero. A esse propósito, é célebre o can. 33, pelo qual proibia-se o uso do matrimônio aos bispos, presbíteros e diáconos durante o exercício de seu ministério. Trata-se da primeira legislação canônica que proíbe o matrimônio ao clero, inaugurando a longa história da vinculação do ministério ordenado à lei do celibato obrigatório.

\subsection{Concílios de Roma}

O primeiro concílio romano de que se tem notícia certa é o que aconteceu sob o Papa Vítor I, em 193, no qual se condenou a prática quatordecimana relativa à data da Páscoa, conforme já indicado. ${ }^{28}$ Em 231, realizou-se um concílio durante o pontificado de Ponciano, para ratificar as medidas tomadas por Demétrio de Alexandria contra Orígenes. ${ }^{29}$

\footnotetext{
${ }^{28}$ DIONISI, U., Roma. Concili, col. 3022-3023.

${ }^{29}$ EUSÉBIO DE CESAREIA, HE, VI,36,4.
} 
Logo após o cisma novacianeo, Cornélio convocou, em 251, um concílio do qual participaram 60 bispos e grande número de presbíteros e diáconos. ${ }^{30}$ Nesse concílio foram condenados Novaciano e seus seguidores. Foram acolhidas as decisões tomadas no Concílio de Cartago (251) a propósito dos lapsi. Em 260. alguns fiéis das igrejas da Pentápolis líbica denunciaram a Roma o caso do bispo de Alexandria, Dionísio, acusando-o de posições trinitárias subordinacionistas e de afirmar que o Filho era criatura $(\pi \circ i ́ \eta \mu \alpha)$. No concílio, Dionísio de Roma condenou tanto o sabelianismo como o triteísmo. Dionísio de Alexandria se retratou e esclareceu alguns pontos extremados de seu pensamento.

Em 30/09/313, reuniu-se uma assembleia de bispos em Roma, na domus Faustae, in Laterano, propriedade imperial, posteriormente doada à Igreja, e transformada na residência oficial de seu bispo. O concílio abordou o tema da controvérsia donatista. Os donatistas, partidários de Donato, acusavam Ceciliano de Cartago de ter sido um traditor na perseguição anterior, além de considerarem inválida sua ordenação episcopal. Defendiam a tradição africana de rebatizar e consideravam inválidos os sacramentos ministrados pelos católicos. O concílio reafirmou a legitimidade da eleição de Ceciliano. No entanto, a questão não se resolveu e perdurou por quase um século, e foi motivo de outros concílios na África.

\subsection{Concílios de Ancira, Neocesareia e Arles}

Em 314, antes de Niceia, reuniram-se três concílios dignos de nota, em Ancira, Neocesareia e Arles, dentre os quais o de Arles é, sem dúvida, o mais importante, com consequências importantes para o futuro da prática conciliar.

O donatismo continuava causando problemas para a unidade da Igreja e a paz do Império. Para dirimir a questão, Constantino convocou um concílio, que se reuniu em Arles (01/08/314), uma das maiores cidades da Gália meridional. Progressivamente a Igreja de Arles adquiriu uma influência cada vez maior, como sé metropolitana e centro de referência da ortodoxia. ${ }^{31}$ Contou com a participação de bispos das Gálias, da Britânia, da Hispânia, da Itália, da Dalmácia e da África. Além do donatismo, foram tratados temas referentes à data da Páscoa, aos traditores, às cartas de comunhão eclesiástica (litterae formatae), ao ministério dos diáconos, à excomunhão e às ordenações. Um dos

\footnotetext{
${ }^{30}$ EUSÉBIO DE CESAREIA, HE, VI,43,2.

${ }^{31}$ MUNIER, C., Arles. Concili, col. 363-366.
} 
pontos mais importantes foi a revisão da questão donatista. Estavam presentes Ceciliano de Cartago e também seus acusadores, os quais, porém, não conseguiram provar as acusações. O concílio de Arles fez suas, por completo, as decisões do concílio de Roma (313); foi reconhecida a inocência de Ceciliano e seus acusadores foram condenados ou expulsos.

Além desta questão, o Concílio unificou a celebração da Páscoa numa mesma data e sugeriu que o Papa fixasse uma data única para toda a cristandade (can. 1). Quanto ao batismo dos hereges, preferiu a posição romana ao invés da africana (can. 9) e retomada depois pelos donatistas. Contra estes, o Concílio de Arles declarou válidas as ordenações conferidas pelos traditori (can. 14). Regulou os deveres do clero: foi-lhes proibido mudar de Igreja (can. 2 e 21), sob pena de deposição, e fazer empréstimos a juros (can. 13). Entre outras determinações, dispuseram a presença de sete, ou de ao menos três bispos, para realizar uma consagração episcopal (can. 20) e proibiram aos diáconos celebrar a Eucaristia (can. 16).

O concílio proibiu os leigos de exercerem a profissão de auriga (can. 4) e de ator (can. 5). Negou-lhes também a autorização para exercer funções municipais e públicas, sem o controle do bispo (can. 7). Foram ameaçados de excomunhão aqueles que tivessem recusado ou desertado do serviço militar (can. 3). Deliberou acerca das condições de acesso ao catecumenato em ponto de morte (can. 6) e para a reconciliação dos apóstatas (can. 22). Regulamentou o uso das cartas de comunhão (can. 10). Recomendou aos maridos abandonados ainda jovens pelas esposas que não contraíssem novo matrimônio, estando ainda vivas as esposas adúlteras (can. 11). Pela diversidade das questões tratadas, este concílio oferece um ótimo panorama dos problemas pastorais e disciplinares, apresentados à Igreja logo após a paz constantiniana. Muitas de suas decisões foram retomadas pelo Concílio de Niceia (325). Por isso, podese concluir que:

Este concílio assinala, de fato, uma passagem epocal na história do cristianismo antigo, porque se configura também como o primeiro concílio geral celebrado no Ocidente, logo após os acordos de Milão (fevereiro 313) entre Constantino e Licínio e ainda como o primeiro concílio a ser convocado pelo imperador. Inaugurava-se assim uma tradição política à qual se reservava um destino particular, e se celebrava tacitamente em anteprima aquela reunião que com maior ressonância seria chancelada alguns anos depois no solene cenário oriental, em Niceia. ${ }^{32}$

${ }^{32}$ BARCELLONA, Introduzione, p. 8. 


\section{Características e eclesiologia emergente dos concílios pré-nicenos}

Os concílios pré-nicenos apresentam características dignas de nota: em geral, participavam muitos bispos; considerava-se maior a autoridade quanto mais numerosos eles fossem. Havia liberdade e franqueza para expor as opiniões e primava-se pela unanimidade das decisões tomadas. Os bispos atribuíam grande autoridade aos concílios, dando-lhes um caráter definitivo. Sentiam-se particularmente comprometidos com as decisões conciliares anteriores, buscando o consenso não apenas num mesmo concílio, mas também entre diversos concílios, porque estava em jogo a comunhão da catholica ecclesia.

$\mathrm{O}$ costume de enviar cartas sinodais às Igrejas irmãs, destinadas a comunicar aos outros bispos as decisões e obter a sua aprovação, são tão antigas como os próprios concílios. O uso remontava à experiência do judaísmo da diáspora e foi adotado pelos cristãos, servindo-lhes para manter e desenvolver a consciência de serem uma unidade de muitas comunidades. Salvaguardavase assim a referência e a autoridade das Igrejas maiores, que passaram pouco a pouco a ter um papel de coordenação. O intercâmbio epistolar, dos centros para as periferias, era habitual por ocasião da Páscoa, pois poucas pessoas estavam em condição de calcular exatamente a data da celebração. ${ }^{33}$

O "mistério da Igreja" não tem ainda nesses primórdios o lugar que passou a ocupar a partir do século IV. Mas na praxe conciliar dos três primeiros séculos emerge uma "eclesiologia de comunhão", que tem por base a Igreja local, fundada sobre o bispo. O conjunto das Igrejas locais forma a Igreja universal. Apesar da dispersão geográfica, a Igreja tem como característica principal e específica a unidade. A unidade da Igreja universal tem como fundamento a "colegialidade episcopal": da unidade do episcopado depende a unidade da Igreja. Os concílios se tornam o lugar privilegiado onde se exercita e se realiza a unidade do corpo episcopal e, em seu ministério, encontra-se presente todo o povo cristão. A partir dessa experiência firmam-se na

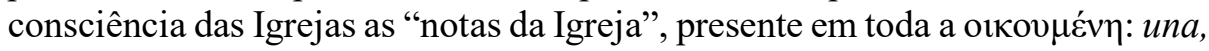
sancta, catholica et apostolica Ecclesia.

\section{Dos concílios regionais ao concílio universal}

A experiência dos primeiros séculos se apresenta como uma preparação para o acontecimento de Niceia. Há um elemento de continuidade: Niceia é uma

${ }^{33}$ DI BERARDINO, A., Percursos de koinonia nos primeiros cristãos, p. 59-61. 
expressão consolidada da "praxe conciliar". Mas há também aspectos de descontinuidade: o instituto do "concílio ecumênico" constituiu um salto de qualidade em relação ao passado. Nenhuma assembleia anterior a 325 teve tanta autoridade e representatividade como Niceia. Numerosas essas reuniões, em nenhum caso, no entanto, atingiram a total participação dos bispos, mesmo em âmbito regional.

O concílio de Niceia codifica uma praxe, muito comum nos inícios do século IV, quando prescreve no cânon 5 sobre a oportunidade de realizar-se sínodos duas vezes por ano. O número dos cristãos, na nova situação, cresce, e ao mesmo tempo surgem também problemas teológicos, organizativos e disciplinares. Os bispos procuram enfrentá-los por meio de frequentes reuniões nas várias partes do império e com a emanação de normas disciplinares, litúrgicas e organizativas. ${ }^{34}$

O "concílio ecumênico" só se tornou possível graças a uma circunstância histórica: a "paz constantiniana", 35 inaugurada pelo Edito de Milão (313), que, privilegiando o cristianismo, deu assim início ao regime de Cristandade, com as perigosas consequências para o futuro da Igreja. A realidade eclesial está na mira da política imperial. A Igreja assume um novo papel público: torna-se a base de apoio do bem-estar e da unidade do Império. Com Constantino, o sínodo obtém um preciso reconhecimento jurídico e suas decisões adquirem efeito de leis imperiais.

Os sínodos ou concílios antigos se diferenciam dos concílios ecumênicos primeiramente por terem surgido espontaneamente, para resolver questões e problemas das igrejas próximas; eram ocasionais. De caráter local ou regional, não tinham força de lei civil, uma vez que a Igreja vivia à margem do Império; a disciplina tinha caráter interno, dizia respeito à vida da Igreja; encontram-se já no séc. III disseminados por todo o Império, no "território cristão". Mesmo em meio às perseguições e insegurança, a Igreja gozava de "liberdade evangélica". Por sua vez, os concílios ecumênicos representavam toda a oikouméne; foram convocados pela autoridade imperial; passaram a ter força de lei imperial, no contexto de uma religião oficial. A liberdade da Igreja vê-se cerceada, condicionada aos interesses do Estado. Os concílios ecumênicos realizaram-se todos na parte oriental do Império. Os sínodos, em Roma, eram

\footnotetext{
${ }^{34}$ DI BERARDINO, A., Presentazione, p. 6.

${ }^{35}$ EUSÉBIO DE CESAREIA, HE, X, 5, 4-14.
} 
presididos por seu bispo, ao passo que nos concílios ecumênicos ele nunca esteve presente, fazendo-se representar por delegados apostólicos.

Segundo G. Alberigo, nos grandes concílios da antiguidade, sobressaem três elementos, advindos provavelmente da prática sinodal, dentro da tradição do cristianismo oriental de língua grega:

A concentração primária na formulação de "profissões de fé" (oroi). Profissões que nascem da vital necessidade de "prestar contas da fé", ainda que em larga medida condicionadas pelo confronto com as correntes heréticas. Às profissões acrescentam-se disposições disciplinares para a vida interna das comunidades (canones). Em segundo lugar, a participação nos trabalhos conciliares é "aberta" tanto a teólogos quanto a leigos, embora essencial (mas não exclusiva) a intervenção dos bispos e, aos poucos, se torne conditio sine qua non o envolvimento dos cinco patriarcas apostólicos (pentarquia). Constitui também um fator bastante destacado a participação de representantes dos ambientes monásticos, dado seu crescente prestígio espiritual e social. ${ }^{36}$

Mesmo com o advento dos grandes concílios ecumênicos (Niceia, Constantinopla, Éfeso, Calcedônia), continuaram a realizar-se sínodos e concílios locais e regionais, tanto no Ocidente como no Oriente. Dão-nos uma ideia dessa vitalidade, só no Ocidente, a informação de que, até o século VII, são computados cerca de 650 concílios: perto de noventa em Cartago, com muitos outros na África (uns dez em Hipona, terra de Agostinho), mais de cem em Roma. ${ }^{37}$ Constatamos, pois, a passagem de uma processualidade sinodal para uma instituição estável, o concílio ecumênico que, no entanto, normatiza, por assim dizer, a dinâmica processual anterior. O concílio ecumênico assumiu o caráter de uma "instância processual oficial", ou seja, um concílio ecumênico é fruto de um processo anterior, com concílios locais e regionais. Ao concluirse, ele abre uma nova etapa, que compreende a sua receptio pelas Igrejas, com o desencadear-se de novos concílios, que levarão, quando as necessidades urgirem, a um novo concílio ecumênico.

\footnotetext{
${ }^{36}$ ALBERIGO, G., Prefácio, p. 5- 6.

${ }^{37}$ DI BERARDINO, A., Presentazione, p. 7.
} 


\section{Conclusão}

Neste breve percurso histórico da prática sinodal, podemos perceber que se comprova a assertiva do Papa Francisco quanto ao Sínodo e, em definitiva, à sinodalidade: esta não é uma novidade na vida da Igreja. A proposta de "caminhar juntos", não apenas para os bispos, mas para todo o corpo eclesial, coloca-se hoje como um imperativo, não só organizacional, mas como um genuíno estilo de vida, que deita duas raízes nas primeiras comunidades cristãs. Estilo que não se definiu a partir de um código de leis abstratas, mas que se foi gestando no percurso do próprio caminho.

No caminho, muitas vezes íngreme e sinuoso, cruzaram-se discípulos (e discípulas!), porta-vozes de comunidades disseminadas por um vasto mundo, caracterizado por problemas comuns e por modos diferenciados de enfrentar as questões e que, no entanto, não foram impedimento para pensar, sentir e agir de maneira colegial, como forma concreta de viver a sinodalidade eclesial, expressão encarnada da comunhão.

A primeira grande prova da Igreja nascente foi aprender a lidar com a diversidade, como aconteceu no "Concílio de Jerusalém". A liberdade para tratar as questões, nos debates acalorados, discussões acirradas, possibilitou a gestão de um "discernimento sinodal", que tem muito a nos ensinar, a fim de vencer o medo e superar os irenismos inócuos, que impedem avançar para novos caminhos, que exigem intrepidez e despojamento, além da abertura e criatividade necessárias.

No cristianismo antigo, clero e leigos participavam juntos, com igualdade de posição. Os confessores tinham grande autoridade e eram consultados, como acontecerá paulatinamente também com os monges, de imensa maioria leiga. No século III, as assembleias sinodais eram públicas, com livre acesso dos fiéis, que podiam intervir nos debates.

A processualidade sinodal dos concílios locais, regionais e nacionais institucionalizou-se no concílio ecumênico. Este, por sua vez, configurou a sinodalidade da vida da Igreja Antiga, contribuindo dessa forma para encontrar soluções novas a problemas novos, no campo da liturgia, doutrina, moral e disciplina. Além de colaborar na elaboração de um "direito canônico" que, no contexto do mundo antigo, teve papel importante no processo de construção da civilização ocidental.

Os concílios são também fonte privilegiada da vida cristã, na medida em que revelam e descrevem vários aspectos da realidade histórica, de modo bastante fiel e objetivo, dando-nos a conhecer o ambiente e o contexto que os 
produziram, bem como a própria maneira de tratar as questões e a evolução do processo decisório, ainda que com suas fórmulas sucintas e repetitivas. ${ }^{38}$

Por fim, no processo de caminho sinodal, a imaginação histórica instiganos a pensar nas muitas pessoas anônimas que, no cotidiano e na rotina de suas comunidades cristãs, se encontravam nas periferias territoriais e existenciais, carregando sua cruz de cada dia, precedidas pelo Ressuscitado nas Galileias de suas terras. No caminho sinodal de hoje são também esses discípulos e discípulas que devem ser considerados na maneira de a Igreja viver e evangelizar, colegial e sinodalmente.

\section{Referências bibliográficas}

ALBERIGO, G. Prefácio. Os concílios ecumênicos na história. In: ALBERIGO, G. (Org.). História dos concílios ecumênicos. São Paulo: Paulus, 2005. p. 5-10.

BARCELLONA, R. Introduzione. In: DI BERARDINO, A. (Org.). I canoni dei concili della Chiesa antica II. I Concili Latini. 2. I Concili Gallici. Roma: Institutum Patristicum Augustinianum, 2010. p. 7-25. (Studia Ephemeridis Augustinianum, 119).

BOTTE, B. La collégialité dans le Nouveau Testament et chez les Pères apostoliques. In: BOTTE, B. Le Concile et les Conciles. Contribution à l'histoire de la vie conciliaire de l'Église. Paris: Ed. De Chevetogne / Ed. Du Cerf, 1960. p. 1-18.

COMISSÃO TEOLÓGICA INTERNACIONAL. A sinodalidade na vida e na missão da Igreja. Brasília: Edições CNBB, 2018. (Documentos da Igreja, 48).

DE LUIS, P. Elvira (Concilio di). In: DI BERARDINO, A. (Dir.). Dizionario Patristico e di Antichità Cristiane. Casale Monferrato: Marietti, 1983. col. 1144-1145. v.I.

DI BERARDINO, A.; GROSSI, V. La Chiesa antica: eclesiologia e istituzioni. Roma: Borla, 1984.

DI BERARDINO, A. Percursos de koinonia nos primeiros cristãos. Concilium, n. 291, p. 46-61, 2001.

${ }^{38}$ BARCELLONA, R., Introduzione, p. 24-25. 
DI BERARDINO, A. Presentazione. In: DI BERARDINO, A. (Org.). I canoni dei concili della Chiesa antica I. I concili greci. Roma: Institutum Patristicum Sugustinianum, 2006. p. 5-8. (Studia Ephemeridis Augustinianum, 95).

DIONISI, U. Roma. Concili. In: DI BERARDINO, A. Dizionario Patristico e di Antichità Cristiane. Casale Monferrato: Marietti, 1984. col. 3022-3023. v.II. EUSÉBIO DE CESAREIA. História Eclesiástica. São Paulo: Novo Século, 2002. FARRELL, J. The Distinction between comitia and concilium. Atheneum, n. 64, p. 407-438, 1986.

FRANCISCO, PP. Commemorazione del $5^{\circ}$ Anniversario dell'Istituzione del Sinodo dei Vescovi. Disponível em: $<$ http://www.vatican.va/content/francesco/it/speeches/2015/october/document s/papa-francesco_20151017_50-anniversario-sinodo.html $>$. Acesso em: 27 abr. 2020.

FRANCISCO, PP. Constituição Episcopalis communio sobre o Sínodo dos Bispos. Brasília: Edições CNBB, 2018. (Documentos Pontifícios, 36).

INÁCIO DE ANTIOQUIA. Epístola aos Filadelfienses. In: CLEMENTE ROMANO et al. Padres Apostólicos. São Paulo: Paulus, 1995. p. 81-146. (Patrística, 1).

JUNOD, E. Naissance de la pratique synodale et unité de l'Église au IIe. Siècle. Revue d'Histoire et de Philosophie Réligieuses, v. 68, p. 163-180, 1988.

LECLERCQ, H. Synode. In: CABROL, F.; LECLERCQ,H. (Orgs.). Dictionnaire d'Archéologie Chrétienne et de Liturgie. Paris: Librairie Letouzy et Ané, 1953. col. 1837-1838.

MAROT, H. Conciles anténicéens et conciles oecuméniques. In: MAROT, H. et al. Le Concile et les Conciles. Contribution à l'histoire de la vie conciliaire de l'Église. Paris: Ed. De Chevetogne / Ed. Du Cerf, 1960. p. 19-43.

MEERK, A. (Ed.). Novum Testamentum Graece et Latine. 5.ed. Roma: Pontificium Institutum Biblicum, 1944.

MUNIER, C. Arles. Concili. In: DI BERARDINO, A. (Dir.). Dizionario Patristico e di Antichità Cristiane. Casale Monferrato: Marietti, 1983. col. 363-366. v.I. 
MUNIER, C. Cartagine. Concili. In: DI BERARDINO, A. (Dir.). Dizionario Patristico e di Antichità Cristiane. Casale Monferrato: Marietti, 1983. col. 600-611. v.I.

NARDI, C. Arabia. In: DI BERARDINO, A. (Dir.). Dizionario Patristico e di Antichità Cristiane. Casale Monferrato: Marietti, 1983. col. 304-306. v.I.

SIMONETTI, M. Alessandria. Concili. In: DI BERARDINO, A. (Dir.). Dizionario Patristico e di Antichità Cristiane. Casale Monferrato: Marietti, 1983. col. 121. v.I.

SIMONETTI, M. Antiochia di Siria. Concili. In: DI BERARDINO, A. (Dir.). Dizionario Patristico e di Antichità Cristiane. Casale Monferrato: Marietti, 1983. col. 233. v.I.

ZEILLER, J. L'Organizzazione ecclesiastica. In: LEBRETON, J.; ZEILLER, J. (Orgs.). Storia della Chiesa II. Dalla fine del II secolo alla pace costantiniana (313). San Paolo: Cinisello Balsamo, 1977. p. 551-573.

\section{Luiz Antônio Pinheiro}

Doutorando em Teologia pela Faculdade Jesuíta de Filosofia e Teologia Bolsista da Capes Docente de História do Cristianismo da Pontifícia Universidade Católica de Minas Gerais Belo Horizonte / MG - Brasil E-mail: lapinheiro1@hotmail.com

Recebido em: 04/05/2020

Aprovado em: 20/05/2020 